\title{
The chemical nature of the bound nicotinic acid of wheat bran: studies of nicotinic acid-containing macromolecules
}

\author{
By J. B. MASON, NORAH GIBSON AND E. KODICEK \\ Dunn Nutritional Laboratory, University of Cambridge \\ and Medical Research Council, Milton Road, Cambridge
}

(Received ${ }_{23}$ October $1972-$ Accepted 9 February 1973)

\begin{abstract}
I. Preparations of bound nicotinic acid obtained from wheat bran by an acid extraction procedure (' niacytin preparations') were resolved into several nicotinic acid-containing components.

2. Extraction of wheat bran under neutral conditions yielded $62 \%$ of the bound nicotinic acid in solution; of this $90 \%$ was non-diffusible. Methods were developed which gave high yields of ' non-diffusible nicotinic acid' preparations.

3. The bound nicotinic acid in the latter preparation was linked to macromolecules of mol. wt about 1500 to 17000 daltons, approximately $60 \%$ of which were polysaccharide and $40 \%$ peptide or glycopeptide in character.

4. o-Aminophenol, and ferulic and sinapic acids, are also contained in macromolecules in wheat bran, but are not directly associated with the bound nicotinic acid.

5. The significance of these results in explaining the nutritional unavailability of bound nicotinic acid is discussed.
\end{abstract}

The association of nicotinic acid deficiency (pellagra) in man with cereal diets is related to the occurrence of the nicotinic acid in cereals in a bound and nutritionally unavailable form (Kodicek, I 962). The metabolic fate of bound nicotinic acid has been accounted for in the nicotinic acid-deficient rat (Mason \& Kodicek, I97o $a, b$ ). The other questions to be answered regarding the nutritional unavailability of bound nicotinic acid concern its chemical structure. This report describes the types of macromolecules in which the bound nicotinic acid of wheat bran is contained.

The nature of the bound nicotinic acid of cereal grains has been studied for over 30 years, since Kodicek (1940 $a, b$ ) found that the nicotinic acid of wheat bran and maize required hydrolysis before it could be extracted. Essentially, there are two views: one is that the nicotinic acid is contained in a polysaccharide (Kodicek \& Wilson, 1960) and the other that it is attached to a peptide (Das \& Guha, I960). Chaudhuri \& Kodicek (1950) first obtained a preparation containing $28 \mathrm{mg}$ nicotinic acid $/ \mathrm{g}$, and their method was developed by Kodicek \& Wilson (1960) to give a preparation containing $50 \mathrm{mg}$ nicotinic acid/g. This sample, which contained $20 \mathrm{mg}$ protein $/ \mathrm{g}$ attributed to an impurity, behaved as a single substance on Tiselius electrophoresis and counter-current distribution and was called 'niacytin'; it was suggested that the nicotinic acid was linked to a polysaccharide chain which was further substituted to a marked extent. On the other hand, Guha and co-workers obtained preparations from rice bran (Guha \& Das, I957) and from wheat bran and maize (Das \& Guha, I960) which contained ro $\mathrm{mg} / \mathrm{g}$ nicotinic acid; these preparations contained protein and it was therefore concluded that the bound nicotinic acid was attached to protein. It was claimed that these preparations, which were called 'niacinogens', were crystalline, 
although this was later refuted, at least for the rice bran 'niacinogen', by Sarkar, Ghosh \& Guha (1962, 1964). The yield of nicotinic acid in the niacytin preparation studied by Kodicek \& Wilson (1960) was less than $2 \%$ of the original nicotinic acid, and the yield of nicotinic acid in the wheat bran niacinogens was about $3 \%$ of the original nicotinic acid (calculated from Das \& Guha, 1960). Christianson, Wall, Dimler \& Booth (1968) also obtained a preparation of bound nicotinic acid from maize gluten that contained, per $\mathrm{g}, 6 \mathrm{mg}$ nicotinic acid, $35^{\circ} \mathrm{mg}$ polysaccharide (as glucose), $20 \mathrm{mg}$ protein (as leucine ninhydrin equivalents) and the remainder 'heterocyclic and aromatic nitrogen compounds'.

The experiments reported here were designed to determine whether the bound nicotinic acid of wheat bran was contained in a single substance or in a number of substances, whether these substances were peptide, polysaccharide, or both, and whether, as suggested by Kodicek \& Wilson (1960), the nicotinic acid was associated with $o$-aminophenol and substituted cinnamic acids.

A preliminary report of the work has been published (Mason, Gibson \& Kodicek, I971).

EXPERIMENTAL AND RESULTS

\section{Nicotinic acid}

\section{Methods of estimation}

Nicotinic acid was extracted from wheat bran and from samples of bound nicotinic acid by a method based on that of Kodicek \& Wilson (1959) (see Mason, 1969). Fractions obtained from gel-filtration of samples of bound nicotinic acid were analysed as follows. To $\mathrm{r} \cdot 0 \mathrm{ml}$ samples of each fraction in graduated stoppered test-tubes, $\mathrm{I} \cdot 0 \mathrm{ml}$ of $2 \mathrm{M}-\mathrm{NaOH}$ was added, and the solution was heated at $100^{\circ}$ for $30 \mathrm{~min}$. After cooling, $\mathrm{r} \cdot \mathrm{O} \mathrm{ml}$ of $2 \mathrm{M}-\mathrm{HCl}$ was added to each solution, followed by $4^{\circ} \mathrm{Oml}$ of $\circ . \mathrm{IM}-$ sodium phosphate buffer $\mathrm{pH} 6.4$ and $3.0 \mathrm{ml}$ ethanol. The concentrations of nicotinic acid in these solutions were then estimated directly (in the same tube) by the method of Mason \& Kodicek (I970a).

\section{o-Aminophenol}

$o$-Aminophenol was estimated by thoroughly mixing the following at room temperature: $\mathrm{I} \cdot 6 \mathrm{ml}$ aqueous sample, or standard solution, $0.4 \mathrm{ml} 0.1 \mathrm{M}-\mathrm{HCl}$ and $\mathrm{I} \cdot 5 \mathrm{ml}$ $p$-dimethylaminobenzaldehyde in ethanol $(20 \mathrm{~g} / \mathrm{l})$. After ro min the extinction of the solution was determined at $434 \mathrm{~nm}$. As a standard, $o$-aminophenol (Fisons Scientific Apparatus Ltd, Loughborough, Leics.) was recrystallized twice from heptane-ethanol mixtures (approximately $7: \mathrm{I}, \mathrm{v} / \mathrm{v}$ ) and a solution of $\mathrm{r} \cdot 0 \mathrm{mg} / \mathrm{ml}$ in ethanol was made up fresh for each estimation and diluted $\mathrm{I}: 100$ with water. Allowance was made for a reagent blank. Estimations of combined $o$-aminophenol in samples of wheat bran were carried out without hydrolysis, which caused rapid destruction of $o$-aminophenol. In preliminary experiments, samples were hydrolysed for varying times, and it was shown that the values extrapolated to zero time agreed with determinations on intact samples. 
Ferulic and sinapic acids

The concentration of ferulic plus sinapic acids in a sample was estimated from the extinction at $323 \mathrm{~nm}$, using the experimentally determined relationship:

$$
\text { ferulic }+ \text { sinapic acids }(\mathrm{mg} / \mathrm{ml})=E_{323} \times 9.9 .
$$

It was found that results obtained from the extinctions of intact samples were very similar to those obtained from the extinctions of extracts prepared by hydrolysis and extraction with dicthyl ether or ethyl acetate. The estimation was therefore carried out on intact samples.

\section{Hexose}

A portion ( $1.0 \mathrm{ml}$ ) of aqueous solution was mixed with Io $\mathrm{ml}$ anthrone reagent, and the reaction was continued as described by Brin (1966). Glucose was used as the standard.

\section{Pentose}

Estimation of pentose, with xylose as a standard, was carried out using orcinol reagent (Brin, 1966).

\section{Protein}

Protein was estimated either by the method of Lowry, Rosebrough, Farr \& Randall (I95I) or by the biuret method (Layne, I957). Bovine plasma albumin (Armour Pharmaceutical Co. Ltd, Eastbourne) was used as a standard. Nitrogen contents were determined on some samples by microanalysis, and the value $\mathrm{N} \times 6.25$ was used as a secondary estimate of the protein content.

\section{Uronic acids}

Uronic acid was estimated by the method of Galambos ( 1967 ), using glucuronic acid as a standard.

\section{Chromatography}

For gel-filtration, Sephadex (Pharmacia Ltd, Uppsala, Sweden) was swollen in water or IM-dimethylformamide for the appropriate times; the Superfine grade of Sephadex G-50 and the Fine grade of G-25 were used. The retention on Sephadex G-5o of substances is given below as the $K_{d}$ values (see Pharmacia Fine Chemicals, 1966). The fractionation range was defined using blue dextran 2000 (Pharmacia Fine Chemicals, Uppsala, Sweden) for the high-molecular-weight end of the range $\left(K_{d}=0 \cdot 0\right)$ and pyridine for the low-molecular-weight end $\left(K_{d}=\mathrm{I} \cdot 0\right)$. Molecular weights were estimated from the values provided by Pharmacia on the basis that the $K_{d}$ value is proportional to the logarithm of the mol. wt (Whitaker, I963). The fractionation range for Sephadex G-50 is $500-10000$ daltons for polysaccharide and $1500-30000$ daltons for peptide. 


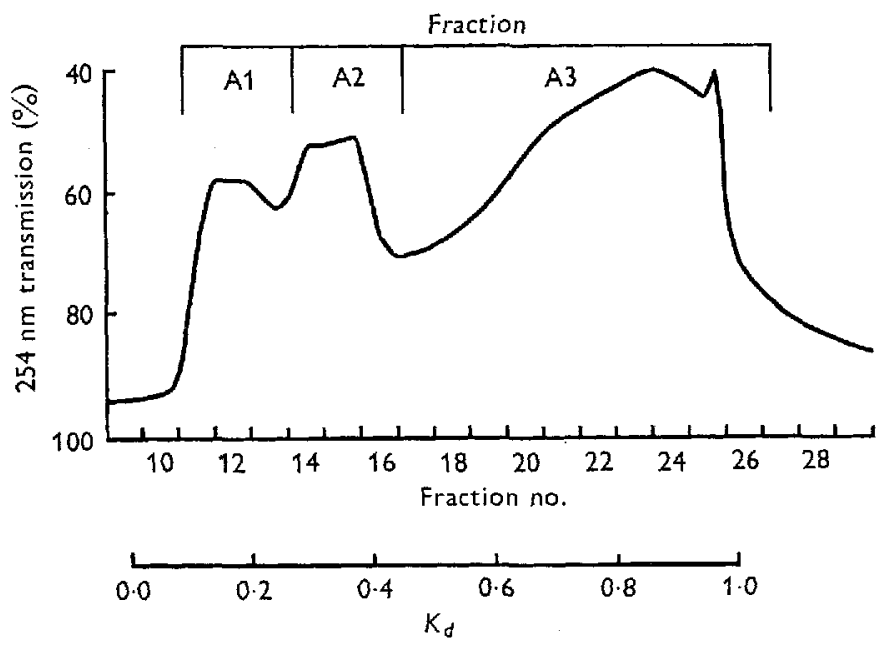

Fig. I. Chromatography of niacytin (20 mg) on Sephadex G-5o, eluted with water. The percentage transmission at $254 \mathrm{~nm}$ is shown. Fractions $(6.0 \mathrm{ml})$ were pooled thus: fraction $\mathrm{A} r$, fractions I1-1 $3 ; \mathrm{A} 2,14-16 ; \mathrm{A} 3,17-26 . K_{d}$ values are derived as described on page 299 .

Diethylaminoethyl(DEAE)-cellulose and carboxymethyl(CM)-cellulose were obtained from Whatman (H. Reeve Angel \& Co. Ltd, I4 New Bridge St, London EC 4 ) in microgranular preswollen form (DE 52 and $\mathrm{CM}_{52}$ ) and precycled according to the manufacturer's instructions. DEAE-cellulose was used in the free base form and CM-cellulose in the sodium form.

Thin layers of Sephadex G-50 and G-25 were used for chromatography by a method similar to that of Morris (I964) and for electrophoresis by a method based on that of Hanson, Johansson \& Rymo (ig66).

For thin-layer ion-exchange chromatography, DEAE-cellulose (DE 52) was used in $0.005 \mathrm{M}$-tris buffer, $\mathrm{pH} 7.25$, in aqueous ethanol $(500 \mathrm{ml} / \mathrm{l})$ by a method similar to that used for Sephadex thin-layer chromatography (see above).

Thin-layer chromatography on silica gel was carried out as described by Mason \& Kodicek (I970a); the solvent system for chromatography of samples of niacytin was propan-2-ol-pyridine-water $\left(4: I_{1}\right.$, by vol.), adjusted to $\mathrm{pH} 6.5$ with glacial acetic acid.

Nicotinic acid-containing substances on thin-layer chromatograms, and in column effluents after application of Io $\mu$ samples to filter paper, were visualized by the method of Kodicek \& Reddi (195I).

\section{Preparations}

\section{Studies on niacytin preparations}

Niacytin was prepared as described by Mason \& Kodicek (1970a). The yield of nicotinic acid was $12 \%$, and the samples contained $20-25 \mathrm{mg}$ nicotinic acid/g. 
Table I. Analyses of fractions of niacytin preparations from gel-filtration and from adsorption chromatography followed by gel-filtration

(Niacytin preparations were chromatographed on Sephadex G-5o to give fractions A I-A 3 , and on silicic acid followed by Sephadex G-50 to give fractions B I and B 2)

\begin{tabular}{|c|c|c|c|c|c|c|c|c|c|}
\hline & \multicolumn{7}{|c|}{$\begin{array}{l}\text { Contents of constituents } \\
\qquad(\mathrm{mg} / \mathrm{g})\end{array}$} & \multicolumn{2}{|c|}{$\begin{array}{l}\text { Molar ratios for } \\
\text { nicotinic acid } \\
=\text { I. } 0\end{array}$} \\
\hline & $\begin{array}{l}\text { Nicotinic } \\
\text { acid }\end{array}$ & $\begin{array}{c}\text { o-Amino- } \\
\text { phenol }\end{array}$ & $\begin{array}{l}\text { Ferulic }+ \\
\text { sinapic } \\
\text { acids }\end{array}$ & Peptide & Hexose & Pentose & Total & $\begin{array}{l}\text { o-Amino- } \\
\text { phenol }\end{array}$ & $\begin{array}{l}\text { Ferulic }+ \\
\text { sinapic } \\
\text { acids }\end{array}$ \\
\hline Niacytin & $28 \cdot 2$ & $17 \cdot 4$ & $21 \cdot 0$ & 492 & 428 & $3^{8}$ & 1025 & 0.69 & 0.45 \\
\hline$A_{I}$ & 14.5 & 10.0 & $22 \cdot I$ & 469 & 375 & 136 & 1027 & 0.78 & 0.90 \\
\hline$A=$ & 30.8 & I $2 \cdot 9$ & 20.0 & $45^{8}$ & 433 & $6_{5}$ & 1020 & 0.47 & 0.38 \\
\hline $\mathrm{A}_{3}$ & $35^{\circ} 9$ & I $5 \cdot 6$ & 19.4 & 402 & $44^{8}$ & $6 I$ & 982 & 0.49 & 0.32 \\
\hline B I & $50 \cdot 9$ & 10.5 & I $4^{*} \mathrm{I}$ & 276 & 467 & $3 I$ & 850 & 0.23 & 0.16 \\
\hline B 2 & $76 \cdot 7$ & $13 \cdot 4$ & I I 8 & 228 & 358 & 26 & 714 & 0.20 & 0.09 \\
\hline
\end{tabular}

\section{Fractionation}

On gel-filtration of niacytin samples on Sephadex G-50, eluted with distilled water, bound nicotinic acid was eluted over the whole fractionation range (see Fig. I). The maxima were found at $K_{d l}$ values of $0.18,0.32$ and $0.88,71 \%$ of the nicotinic acid being in the lowest mol. wt fraction (A 3, Fig. I). The mol. wts equivalent to these $K_{d}$ values were approximately 6000,4000 and 700 daltons for polysaccharide and 17000,12000 and 2000 daltons for peptide.

Niacytin was also fractionated by several other procedures. Column chromatography on silicic acid, elution with water and aqueous ethanol $(700 \mathrm{ml} / \mathrm{l})$ followed by gel-filtration yielded a number of separate nicotinic acid-containing substances. Thinlayer chromatography on silica gel also separated niacytin into at least six nicotinic acid-containing substances.

\section{Analysis}

Fractions of niacytin preparations were analysed for nicotinic acid, $o$-aminophenol, ferulic + sinapic acids, protein, hexose and pentose; selected results are given in Table I. It was found that even fractions containing high concentrations of nicotinic acid (e.g. fraction $\mathrm{B} 2,77 \mathrm{mg}$ nicotinic acid/g) contained considerable amounts of peptide, in contrast to previous conclusions that niacytin contained no protein (Kodicek \& Wilson, 1960). The molar ratios of $o$-aminophenol and of ferulic + sinapic acid to nicotinic acid were invariably less than unity (Table 1 ). Thus 0 -aminophenol, ferulic and sinapic acids are certainly not invariably associated with the bound nicotinic acid moieties, and therefore could not be responsible for the unavailability of bound nicotinic acid by exerting steric hindrance on the nicotinoyl-macromolecule bond, as had been previously suggested (Kodicek \& Wilson, 1960).

Since several nicotinic acid-containing macromolecules were found in the niacytin preparations, a new preparative procedure was developed which minimized the possibility of hydrolysis during extraction and which gave higher yields, to ensure that different forms of bound nicotinic acid, if they existed, could be recovered. 


\section{Table 2. Extraction of bound nicotinic acid from wheat bran}

(Wheat bran ( $100 \mathrm{~g}$ ) was extracted sequentially with the solvents shown, at $4^{\circ}$ for $\mathrm{I} h$; the supernatant fractions were collected and the bound nicotinic acid was extracted and estimated as described on p. 298)

$\begin{array}{clc}\begin{array}{c}\text { Supernatant } \\ \text { fraction no. }\end{array} & \begin{array}{c}\text { Nicotinic acid } \\ \text { extracted }(\% \text { of that } \\ \text { in the starting } \\ \text { material) }\end{array} \\ \text { I } & \text { Solvent } & 42 \\ 2 & \text { Aqueous ethanol }(500 \mathrm{ml} / \mathrm{l}), 2 \text { 1 } & \text { I I } \\ 3 & \text { Aqueous ethanol }(500 \mathrm{ml} / 1), \text { I l } & 9 \\ 4 & \text { Aqueous ethanol }(500 \mathrm{ml} / 1), \text { I } 1 & \text { I I } \\ 5 & \text { Water, I I } & 9\end{array}$

Table 3. Preparation of 'non-diffusible nicotinic acid' from wheat bran

(Experimental details are given below)

\begin{tabular}{|c|c|c|c|c|}
\hline \multirow[b]{2}{*}{ Step } & Nicotinic ac & $\begin{array}{l}\text { Tield } \\
\text { otinic } \\
\text { n prer }\end{array}$ & & \multirow[b]{2}{*}{$\begin{array}{c}\text { Purification } \\
\text { (n-fold) }\end{array}$} \\
\hline & $\begin{array}{l}\text { content } \\
(\mathrm{mg} / \mathrm{g})\end{array}$ & $\begin{array}{l}\text { step } \\
(\%)\end{array}$ & $\begin{array}{c}\text { Total } \\
\text { yield }(\%)\end{array}$ & \\
\hline Wheat bran & 0.209 & $\ldots$ & - & - \\
\hline $\begin{array}{l}\text { (I) Aqueous ethanol }(500 \mathrm{ml} / \mathrm{l}) \\
\text { then extraction with diethyl ether }\end{array}$ & $I \cdot 26$ & 60 & 60 & $6 \cdot 0$ \\
\hline (2) Dialysis & - & 90 & 54 & - \\
\hline (3) Centrifugation & $3 \cdot 44$ & 79 & 47 & $16 * 4$ \\
\hline
\end{tabular}

\section{Preparation}

Studies on 'non-diffusible nicotinic acid' preparations

To investigate the extraction of bound nicotinic acid from wheat bran, the following experiment was done. Wheat bran ( $100 \mathrm{~g}$ ) was stirred with 21 aqueous ethanol $(500 \mathrm{ml} / \mathrm{l})$ at $4^{\circ}$ for $\mathrm{I} h$. The suspension was then passed through gauze with squeezing to filter off the liquid. The filtrate was centrifuged at $4000 \mathrm{~g}$ for $30 \mathrm{~min}$ and the supernatant liquid was kept. The pellet was added to the residue and both were extracted again with $\mathrm{I} l$ of the aqueous ethanol at $4^{\circ}$ for $\mathrm{I} h$. After filtration and centrifugation the supernatant fraction was taken exactly as before. This process was repeated a third time. The residue was then extracted similarly twice with I 1 water, and after filtration and centrifugation the supernatant liquids were again taken. Portions (20 mi) of the supernatant liquids at each stage were hydrolysed and the content of nicotinic acid was determined; the nicotinic acid content of a sample of the residue was also determined. The distribution of nicotinic acid in the extracts is shown in Table $2 ; 62 \%$ of the nicotinic acid was in the aqueous ethanol extracts. The aqueous ethanol supernatant fractions were pooled and reduced to dryness by vacuum distillation at $40^{\circ}$ followed by freeze-drying. The solid material ( $10.2 \mathrm{~g}$ ) was then extracted twice with $200 \mathrm{ml}$ diethyl ether by suspension, mixing and centrifugation. After removal of traces of ether under reduced pressure, $9.5 \mathrm{~g}$ of solid were collected, which had a nicotinic acid content of $\mathrm{I} \cdot 26 \mathrm{mg} / \mathrm{g}$, giving a recovery of $60 \%$ nicotinic acid from the starting material and a sixfold purification (Table 3 ).

Several purification procedures were attempted on this extract, the most successful 
$1 \mathrm{~kg}$ wheat bran, extracted with 8 aqueous ethanol $(500 \mathrm{ml} /$ ) for $12 \mathrm{~h}$

at $4^{\circ}$. Filtered through gauze and then filter-paper. Filtrate

centrifuged at $1200 \mathrm{~g}$ for $30 \mathrm{~min}$

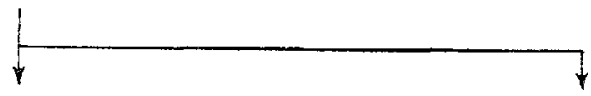

Supernatant $(6 \mathrm{I})$ reduced to dryness, by vacuum distillation

Residue discarded

at $40^{\circ}$, followed by freeze-drying

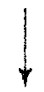

Solid material (approx. $75 \mathrm{~g}$ ) extracted twice with

1 I diethyl echer, centrifuged at $2000 \mathrm{~g}$ for $30 \mathrm{~min}$

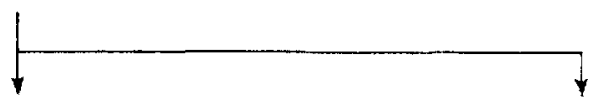

Residue (approx. $72 \mathrm{~g}$ ) suspended in

Residue discarded

water at a concentration of $40 \mathrm{~g} / \mathrm{l}$.

centrifuged at $1200 \mathrm{~g}$ for $1 \mathrm{~h}$ at $4^{\circ}$

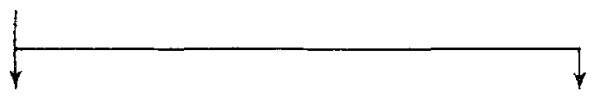

Supernatant dialysed against 3 changes of

Residue discarded

25 I tap-water per I of supernatant

for $24 \mathrm{~h}$ at $4^{\circ}$

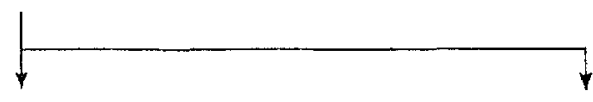

Non-diffusible suspension centrifuged at $10000 \times \mathrm{g}$ for $30 \mathrm{~min}$ at $4^{\circ}$.

Diffusate discarded

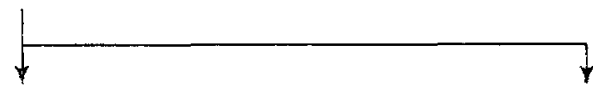

Supernatant freeze-dried. Approx.

Residue discarded

$21 \mathrm{~g}$ solid collected, containing

$3.1 \mathrm{mg}$ nicotinic acid $/ \mathrm{g}$, i.e.

$31 \%$ yield of nicotinic acid

Fig. 2. Preparation of 'non-diffusible nicotinic acid' from wheat bran.

being dialysis: $\mathrm{I} \cdot \mathrm{O} \mathrm{g}$ of the extract was dissolved in $50 \mathrm{ml}$ aqueous ethanol $(500 \mathrm{ml} / \mathrm{l})$, and the solution was dialysed in Visking dialysis tubing against four changes of $45^{\circ} \mathrm{ml}$ distilled water at $4^{\circ}$ over a period of $24 \mathrm{~h}$. During removal of ethanol during dialysis, a precipitate formed which was removed by centrifugation at $12000 \mathrm{~g}$ at $4^{\circ}$ for $\mathrm{I} h$. The pellet was redissolved in $80 \mathrm{ml}$ aqueous ethanol, and proportions of this solution, of the supernatant liquid and of the diffusate were hydrolysed and analysed for nicotinic acid: $10 \%$ of the nicotinic acid was present in the diffusate, and $90 \%$ of the nicotinic acid in the extract was non-diffusible. Of the non-diffusible material, $12 \%$ of the nicotinic acid was in the precipitate, and thus $79 \%$ of the extracted nicotinic acid was in the non-diffusible supernatant liquid (Table 3). After freeze-drying of this solution, the solid contained $3.44 \mathrm{mg}$ nicotinic acid/g. The total yield of nicotinic acid from wheat bran to this stage was $47 \%$, with a purification of $16 \cdot 4$ times (Table 3 ). 

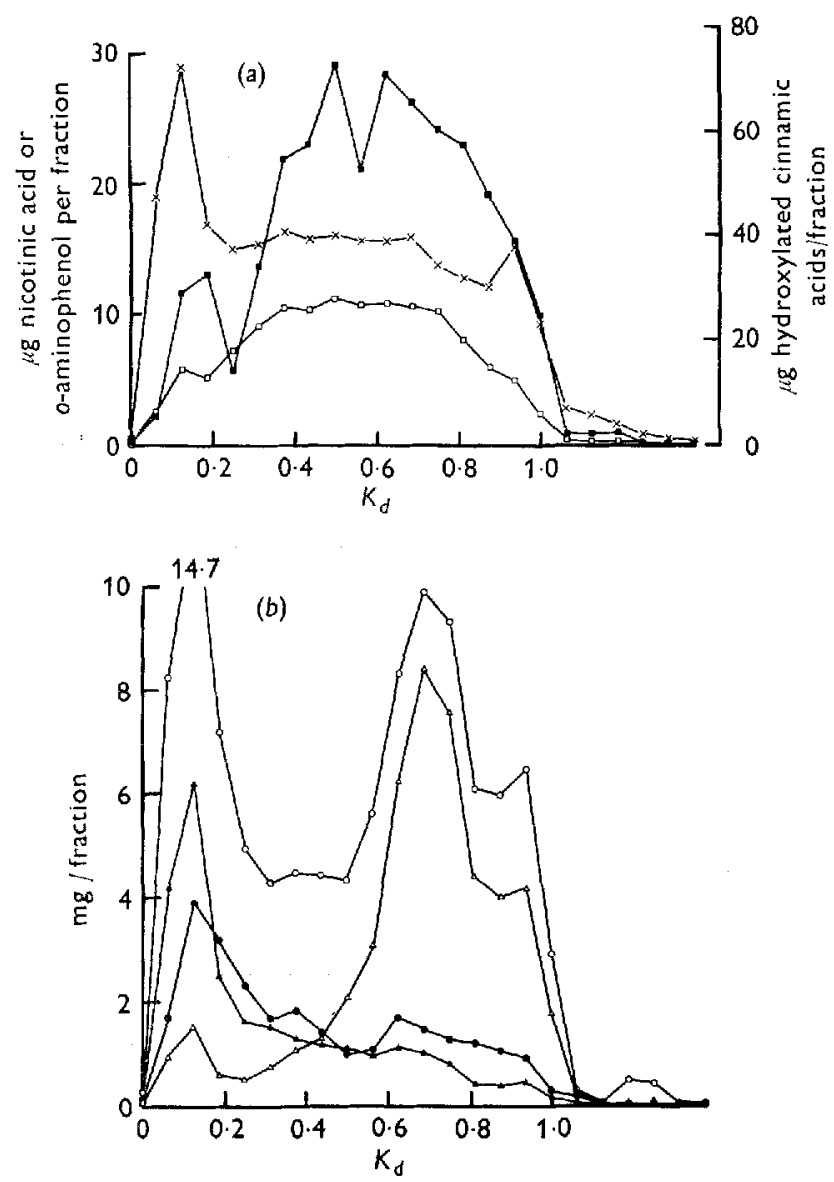

Fig. 3. Chromatography of 'non-diffusible nicotinic acid' preparation (100 mg) on Sephadex G-50 eluted with aqueous M-dimethylformamide. Fractions were analysed for the components shown as described on p. 299. (a) For nicotinic acid (n- - a ) and o-aminophenol ( $\square-\square)$ the ordinate is on the left; for hydroxylated cinnamic acid $(x-x)$ on the right. $K_{d}$ values are derived as described on p. 299. (b) $\mathrm{O}-\mathrm{O}$, total weight of each fraction; $-\triangle$, peptide; $\triangle-\triangle$, hexose; $\triangle-\Delta$ pentose. $K_{d}$ values are derived as described on p. 299.

From this experiment a routine large-scale procedure (Fig. 2) was developed for preparation of 'non-diffusible nicotinic acid', referred to henceforth as 'NDN'. Recoveries of $30-40 \%$ were obtained.

\section{Fractionation ( $\mathrm{I}$ )}

Solvent extraction. A solvent extraction procedure, as used by Mason \& Kodicek (1970a), was applied to a sample ( $\mathrm{I} \mathrm{g}$ ) of NDN. The yield was $45 \mathrm{mg}$ of material equivalent to niacytin, containing $34 \mathrm{mg}$ nicitinic acid/g, which amounted to a $40 \%$ yield. 'This material is referred to as 'sample C'.

Gel-filtration. The most satisfactory eluting solvent for chromatography on Sephadex was aqueous $\mathrm{M}$-dimethylformamide, suggested by the work of Simmonds \& 
Winzor (1961) on the chromatography of wheat proteins. Aqueous ethanol $(500 \mathrm{ml} / \mathrm{l})$, as used by Christianson et al. (1968), gave poor resolution, probably owing to the inadequate swelling of Sephadex in this solvent. Water was also unsatisfactory, owing to the low solubility of the NDN in water, a $4 \%$ solution being saturated. A solution containing at least $20 \% \mathrm{NDN}$ was obtained in aqueous M-dimethylformamide.

Samples of NDN ( $100 \mathrm{mg}$ ) were dissolved in $\mathrm{r} \cdot \mathrm{O} \mathrm{ml}$ aqueous $\mathrm{M}$-dimethylformamide and applied to a $\mathrm{r} \cdot 5 \times 75 \mathrm{~cm}$ column of Sephadex G-50 equilibrated with this solvent, and elution was carried out with aqueous M-dimethylformamide at a flow rate of $8 \mathrm{ml} / \mathrm{h}$. Fractions $(5 \cdot 2 \mathrm{ml})$ were collected and each fraction was transferred to a weighed $25 \mathrm{ml}$ glass vial. The contents of the vials were freeze-dried and re-weighed, and the weight of the contents was calculated by difference. The weighing error was estimated at $0.2 \mathrm{mg}$, which was less than $5 \%$ of the average weight of the contents. The residue was then dissolved in $5^{\circ} \mathrm{O} \mathrm{ml}$ aqueous $\mathrm{M}$-dimethylformamide, and samples of these solutions were taken for estimation of nicotinic acid, $o$-aminophenol, ferulic and sinapic acids, peptide, hexose and pentose.

These results are shown in Fig. $3(a, b)$. From the distribution of nicotinic acid (Fig. $3 a$ ) over the entire fractionation range, it is concluded that there are a number of components that contain nicotinic acid. The $K_{d}$ values of the fractions containing the maximum concentrations of nicotinic acid were $0.19,0.50$ and 0.63 , with the highest nicotinic acid concentration $(0.66 \%)$ in the fraction at $K_{d}=0.50$. The major nicotinic acid-containing fraction from niacytin was at $K_{d}=0.88$ (see Fig. I) and was thus of lower mol. wt than the major components of NDN. This provided evidence that the bound nicotinic acid molecules had indeed been hydrolysed during the acid extraction procedure used in the preparation of niacytin samples. These $K_{d}$ values of NDN $(0.19,0.50$ and 0.63$)$ indicated mol. wts for polysaccharide of 5600 , 2200 and 1500 daltons, and for peptide of 17000,6600 and 4500 daltons, respectively.

The $o$-aminophenol-containing macromolecules did not co-chromatograph exactly with the nicotinic acid-containing molecules, and there was considerably less $o$-aminophenol present than nicotinic acid. Hydroxylated cinnamic acids were also incorporated in macromolecules, and it is not surprising therefore that these compounds contaminated niacytin preparations. Protein and macromolecules containing pentoses (hemicelluloses) were generally of relatively high mol. wt with maxima at $K_{d}=0.12$, whereas the hexoses were of lower mol. wt with the maxima at $K_{d}=0.69$ (Fig. $3 b$ ).

Ion-exchange chromatography. The wheat proteins, gliadin and glutenin, which contain a high proportion of glutamic acid, are insoluble in water but soluble in mixtures containing organic solvents, such as $700 \mathrm{ml} / 1$ aqueous ethanol (Horder, Dodds \& Moran, 1954). It was possible that the proteins contained in NDN, which are soluble in $500 \mathrm{ml} / 1$ aqueous ethanol, were similar and would therefore be retained on an anion-exchange resin. On the other hand, a cation-exchange resin (Amberlite IRC-50) was used by Christianson et al. (1968) to remove zein from samples of bound nicotinic acid prepared from maize gluten.

In preliminary experiments it was found that on the cation-exchange medium CM-cellulose at $\mathrm{pH} 4 \cdot 2$, only $6 \%$ of the nicotinic acid and very little protein was retained; at $\mathrm{pH} 6.7$ no material at all was retained. When the anion-exchanger 


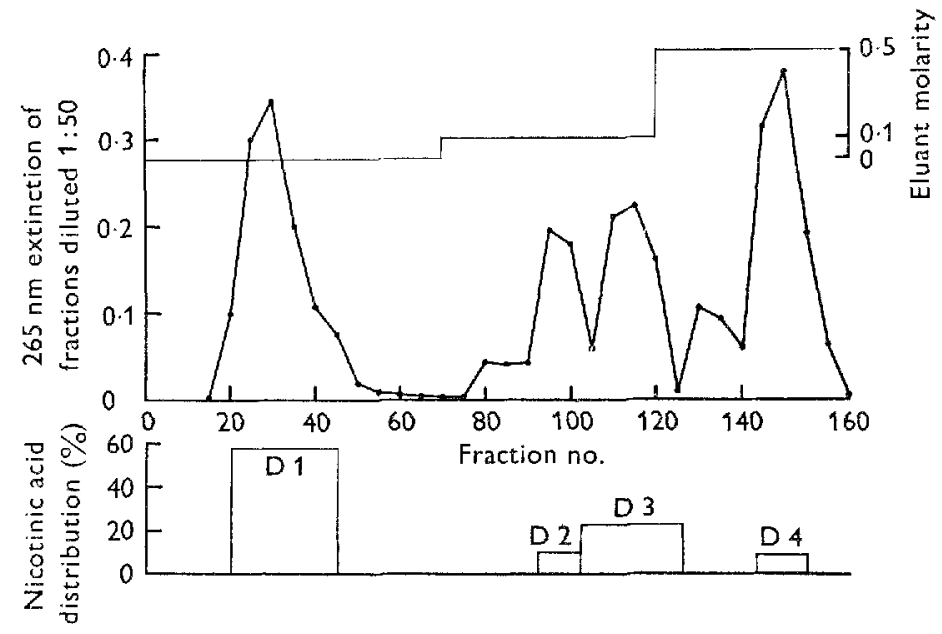

Fig. 4. Preparative ion-exchange chromatography of 'non-diffusible nicotinic acid' preparation ( $10 \mathrm{~g}$ ) on DEAE-cellulose at $\mathrm{pH} 7 \cdot 3$ with stepwise elution with increasing concentrations of tris buffer in aqueous ethanol $(500 \mathrm{ml} / 1)$. The $u . v$. extinction of fractions diluted $1: 50$ with aqueous ethanol $(500 \mathrm{ml} / \mathrm{l})$ is shown. Fractions ( $10 \mathrm{ml}$ ) were pooled to give fractions $\mathrm{D}_{\mathrm{I}}-\mathrm{D}_{4}$ thus: $D_{1}$, fractions $20-45 ; D_{2}, 92-102 ; D_{3}, 10_{3}-126 ; D_{4}, 143-155$. The distribution of the nicotinic acid recovered in these fractions is shown in the lower part of the figure.

DEAE-cellulose was used approx. $40 \%$ of the nicotinic acid and $85 \%$ of the protein in $\mathrm{NDN}$ was retained at $\mathrm{pH} 7 \cdot 3-7 \cdot 5$. With $\mathrm{pH}$ values significantly above neutrality this procedure could not be used because of the lability of the bound nicotinic acid.

On a preparative scale NDN ( $\mathrm{I} \circ \mathrm{g}$ ) was applied to a $3^{\circ} \circ \times 37 \mathrm{~cm}$ column of DEAEcellulose equilibrated with $0.005 \mathrm{M}$-tris buffer $\mathrm{pH} 7.3$ in aqueous ethanol $(500 \mathrm{ml} / \mathrm{l})$. The eluting solutions, which were made up in aqueous ethanol $(500 \mathrm{ml} / \mathrm{l})$ were: $700 \mathrm{ml}$

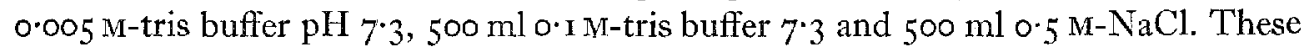
were applied stepwise to the column. Fractions were pooled and their nicotinic acid contents were determined, as shown in Fig. 4. The fractions are referred to as D I-D 4, and thcy correspond to peaks of nicotinic acid elution, detected by the colour reaction on filter paper (see p. 300). Of the nicotinic acid recovercd ( $96 \%$ of that applied) $58 \%$ was in fraction $\mathrm{D}_{1}, 10 \%$ in $\mathrm{D}_{2}, 23 \%$ in $\mathrm{D}_{3}$, and $9 \%$ in $\mathrm{D}_{4}$. Of the protein $85 \%$ was retained. Fractions D I-D 4 were then collected as solids after freeze-drying and studied furthcr. Although a certain amount of hydrolysis of the retained fractions (D 2-D 4) was detected by subsequent gel-filtration, no hydrolysis to free nicotinic acid occurred. This hydrolysis did not affect the conclusions reached concerning the nature of the bound nicotinic acid in the fractions $\mathrm{D}_{2-}-\mathrm{D}_{4}$ (see below).

The presence of both ionizable and non-ionizable molecules in NDN, and their separation by column ion-exchange chromatography, was confirmed by thin-layer ion-exchange chromatography (see p. 300 ).

\section{Analyses}

The contents of nicotinic acid, $o$-aminophenol, ferulic + sinapic acids, peptide (biuret method and $\mathrm{N} \times 6 \cdot 25$ ), hexose and pentose were determined for the following 
Table 4. Analyses of 'non-diffusible nicotinic acid' preparations and of fractions obtained by solvent extraction and by ion-exchange chromatography

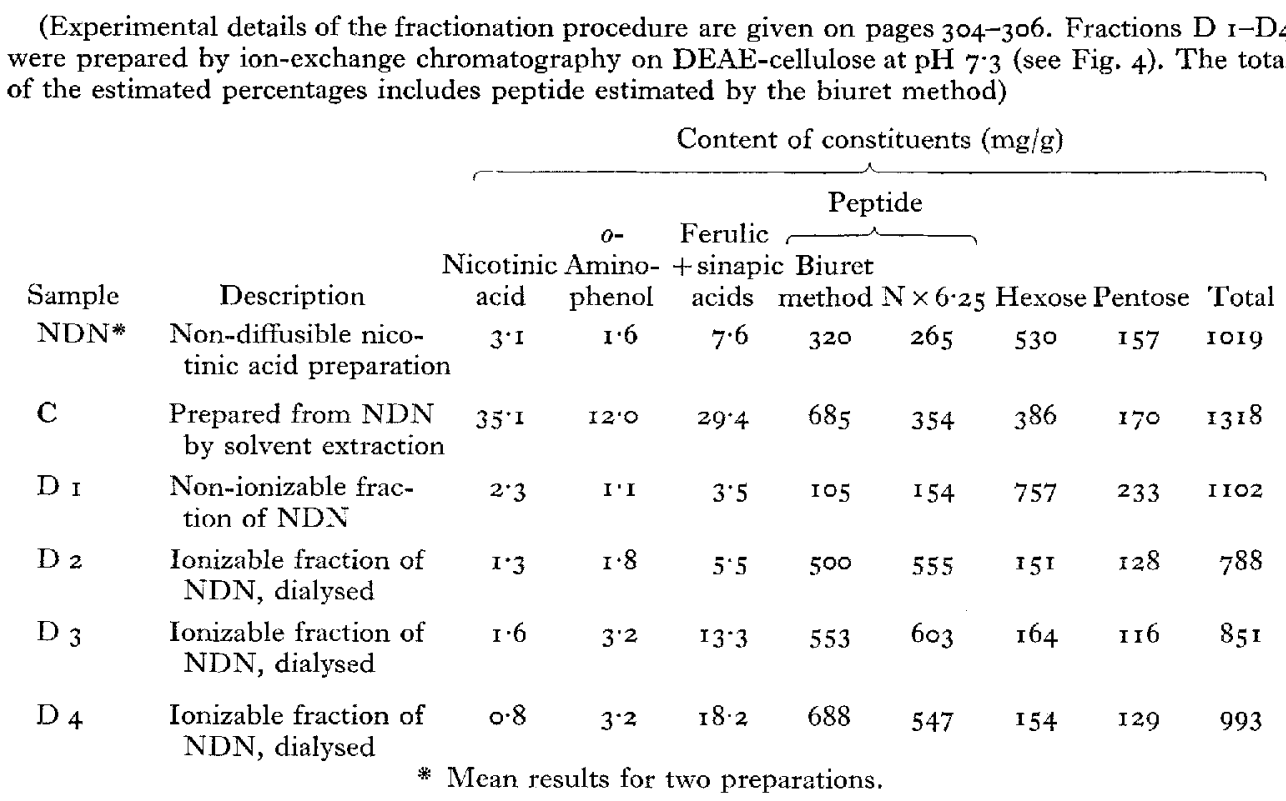

samples: NDN, sample C, fraction D I, and fractions D 2-D 4 after dialysis to remove buffer. Fractions D 2-D 4 were also analysed for hexuronic acids, and the content was found to be less than $2 \%$ in each fraction. The $N$ content of NDN, fraction D I, and fractions $\mathrm{D}_{2-\mathrm{D}} 4$ (dialysed) was also determined. The results are given in Table 4. Fractions $\mathrm{D}_{2}-\mathrm{D}_{4}$ were also analysed before dialysis, and the results confirmed that the proportions of the major constituents were largely unchanged by dialysis. Since the recovery totals IoI $9 \mathrm{mg} / \mathrm{g}$ for NDN, the components analysed should account for everything in the extracts. The recovery was calculated using the peptide content as determined by the biuret method; for fraction $D_{I}$ the total recovery would presumably be more accurate $(987 \mathrm{mg} / \mathrm{g})$ if the peptide content were calculated as $\mathrm{N} \times 6.25$.

These results show that the non-retained fraction, D I, contained about $90 \%$ carbohydrate and only about 10\% peptide. The portion of nicotinic acid that was not retained on DEAE-cellulose $(58 \%$ of that in NDN, fraction D I) must be present in molecules that are uncharged at $\mathrm{pH} 7 \cdot 3$ to $7 \cdot 5$; moreover, since very little retention $(6 \%)$ of the nicotinic acid in NDN occurred on CM-cellulose, most or all of these molecules were uncharged at low $\mathrm{pH}$ also. Thus $58 \%$ of the nicotinic acid in NDN was attached to non-ionizable molecules. Since this nicotinic acid that was attached to uncharged molecules is present in a fraction that contained $90 \%$ carbohydrate (i.e. approx. $70 \%$ hexose and $20 \%$ pentose) and only $10 \%$ protein, it is very likely that the nicotinic acid was attached to macromolecules that are polysaccharide in character. The other portion of the nicotinic acid ( $42 \%$ of that in NDN) found in the molecules retained on DEAE-cellulose, that is those that were charged at $\mathrm{pH} 7 \cdot 3-7 \cdot 5$, was present in fractions that contained about $60 \%$ peptide. Thus it is very likely that 


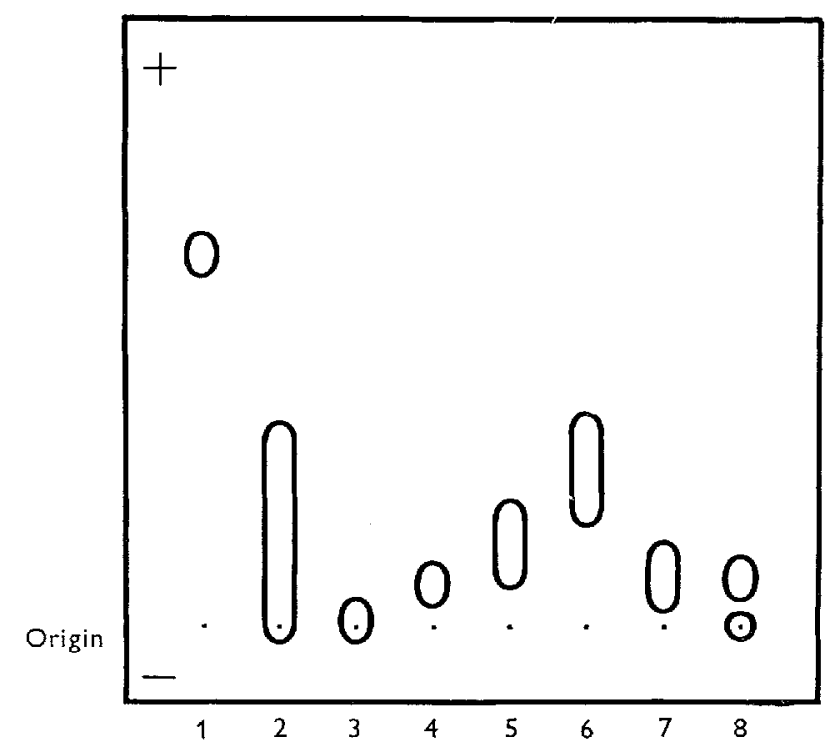

Fig. 5. Thin-layer electrophoresis on Sephadex G-25, in aqueous triethanolamine (roo ml/1) adjusted to $\mathrm{pH}_{7 \cdot 3}$ with acetic acid. The technique is described on $\mathrm{p} .300$. The samples applied, which contained approx. $2 \mu \mathrm{g}$ nicotinic acid, were: $\mathrm{I}$, nicotinic acid; 2 , 'non-diffusible nicotinic acid' preparation; 3 , fraction $\mathrm{D}_{1} ; 4$, fraction $\mathrm{D}_{2} ; 5$, fraction $\mathrm{D}_{3} ; 6$, fraction $\mathrm{D}_{4}$; 7 , sample C (see p. 304); 8, niacytin preparation. The conditions were $250 \mathrm{~V}, 55 \mathrm{~mA}, 3.5 \mathrm{~h}$ at $0^{\circ}$; the mobility of nicotinic acid was approx. $8 \times 10^{-9} \mathrm{~m}^{2} / \mathrm{s}$ per V.

this nicotinic acid was associated with peptide, which was ionized at $\mathrm{pH} 7 \cdot 3-7 \cdot 5$. 'The macromolecules that contained 0 -aminophenol and the hydroxylated cinnamic acids were concentrated in the retained peptide fractions, but occur also in the uncharged carbohydrate macromolecules.

The analysis of sample $\mathrm{C}$, prepared from NDN by the solvent extraction procedure used for niacytin preparations, showed that it contained $35^{\circ} \mathrm{I} \mathrm{mg}$ nicotinic acid/g (see Table 4), similar to niacytin, and a considerable amount of protein. The solvent extraction procedure also concentrated substances that contained 0 -aminophenol and hydroxylated cinnamic acids.

\section{Fractionation (2)}

Gel-filtration. By repeated chromatography of samples of fractions D I on columns and thin layers of Sephadex G-5o it was shown that there were a number of nicotinic acid-containing macromolecules in this fraction. No single compound could be isolated.

Electrophoresis. Electrophoresis was carried out with thin layers of Sephadex G-25 as an inert support, other support media such as paper, cellulose acetate and polyacrylamide gel being unsatisfactory because of poor resolution and difficulties in staining. No migration of fractions $\mathrm{D} \mathrm{I}-\mathrm{D}_{4}$ or of $\mathrm{NDN}$ occurred at $\mathrm{pH}_{3} \cdot 6$ in aqueous M-dimethylformamide-acetic acid buffer. However, in aqueous triethanolamine ( $100 \mathrm{ml} / \mathrm{l}$ ) adjusted to $\mathrm{pH} 7 \cdot 3$ with glacial acetic acid the results shown in Fig. 5 were 
obtained. At this $\mathrm{pH}$, fraction $\mathrm{D}$ I was uncharged and the mobilities of fractions $\mathrm{D}_{2}, \mathrm{D}_{3}$ and $\mathrm{D}_{4}$ increased in numerical order, as expected. NDN was shown to contain fractions $\mathrm{D} \mathrm{I}_{-}-\mathrm{D}_{4}$. This further confirmed that both ionizable and nonionizable nicotinic acid-containing macromolecules were present in NDN preparations. Sample C had similar mobility to fractions $\mathrm{D}_{2}$ and $\mathrm{D}_{3}$, and the niacytin preparation was resolved into a charged and an uncharged spot. Thus the bound nicotinic acid was linked to charged molecules (presumably peptide), entirely in sample $\mathrm{C}$ and partly in niacytin.

\section{DISCUSSION}

Samples of bound nicotinic acid prepared by previously developed methods that included an acid extraction step (Chaudhuri \& Kodicek, I950; Kodicek \& Wilson 1960) were first studied. These samples ('niacytin' preparations) could be resolved into a number of nicotinic acid-containing macromolecules, but no fractions were obtained in which the bound nicotinic acid was separated from peptide, in contrast to previous findings (Kodicek \& Wilson, 1960). Moreover, the amounts of o-aminophenol and of ferulic and sinapic acids present were insufficient to cause the bound nicotinic acid to be nutritionally unavailable by exerting steric hindrance on the nicotinoyl-macromolecule bond, as was suggested by Kodicek \& Wilson (1960).

To determine whether one or more forms of bound nicotinic acid were present in wheat bran, a mild, neutral chemical procedure was developed for extraction of the bound nicotinic acid from wheat bran in high yields. Using aqueous ethanol $(500 \mathrm{ml} / \mathrm{l})$ at $4^{\circ}$, about $60 \%$ of the bound nicotinic acid of wheat bran was extracted, of which $90 \%$ was non-diffusible. Preparations that contained about $3 \mathrm{mg}$ nicotinic acid/g were obtained by this method and are referred to as 'non-diffusible nicotinic acid' $(\mathrm{NDN})$ preparations.

Gel-filtration of samples of NDN showed that this preparation also contained a number of different nicotinic acid-containing substances. It was concluded therefore that in this preparation the bound nicotinic acid was not present as a single substance, but was contained in a number of substances of different mol. wts, from about 1500 to I 7000 daltons. Since bound nicotinic acid was eluted throughout the entire fractionation range of Sephadex $\mathrm{G}-5^{\circ}$, gel-filtration was not successful in further purification. Analysis of other components of the NDN preparations after fractionation on Sephadex did not indicate that the nicotinic acid was exclusively associated with any one of these components. Whether the macromolecules that contained nicotinic acid were primarily polysaccharide or peptide was studied by ion-exchange chromatography and electrophoresis. Evidence was obtained that approximately $60 \%$ of the nicotinic acid was attached to polysaccharide. The ionizable fractions were shown by analysis to contain neutral sugars, which must themselves have been linked to ionizable molecules to have been retained. The ionizable molecules were thought to be peptide since no other ionizable molecules were detected and, certainly in the NDN samples, all the constituents of the sample were accounted for on analysis. Since the retained fractions contained neutral sugars attached to peptide, the nicotinic acid was probably linked to peptide or glycopeptide. 
Extraction of NDN by the procedure for preparation of niacytin, with a yield of $40 \%$, gave a sample (C) that contained $350 \mathrm{mg}$ protein $/ \mathrm{g}$ and on electrophoresis had a similar mobility to that of the fractions retained on DEAE-cellulose. It would seem therefore that this procedure tended to extract preferentially the nicotinic acidcontaining macromolecules that contain protein. The samples of niacytin containing $50 \mathrm{mg}$ nicotinic acid/g, studied by Kodicek \& Wilson (1960), contained less than $20 \mathrm{mg}$ protein/g. It is likely that one particular nicotinic acid-containing macromolecule was preferentially extracted, which in this instance did not contain protein.

These studies on the nature of the NDN preparations, which were extracted so as to minimize hydrolysis, explain the existence of the two views of the nature of bound nicotinic acid, namely that it is attached to polysaccharide (Kodicek \& Wilson, I960) or to peptide (Das \& Guha, 1960): the present results show that it is in fact attached to both.

The nutritional availability of bound nicotinic acid must ultimately be explained in terms of its chemical structure. Although complete structural analysis of the bound nicotinic acid-containing macromolecules was not practicable, certain conclusions may be drawn. The nicotinoyl moicty is contained in molecules that are cellulose or hemicellulose in nature, since the hexose-containing components are known to be $\beta \mathrm{r}-4$-linked (Kodicek \& Wilson, I 960 ), as in cellulose, and the pentoses in plant tissues are largely contained in hemicelluloses. Such molecules are very resistant to hydrolysis by digestive enzymes. Thus the unavailability could be due to these molecules restricting access of digestive enzymes to the nicotinic acid-macromolecule bond, so that free nicotinic acid is not made available for absorption. The possibility that molecules such as $o$-aminophenol exerted steric hindrance on the bond was excluded by these experiments.

This work has also shown that in the outer layers of the wheat seed there are polysaccharides and peptides to which a number of different molecules are attached. Not only nicotinic acid, but also o-aminophenol, ferulic and sinapic acids, were found to be present in relatively small macromolecules, and no doubt other aromatic and heterocyclic compounds could have been detected.

To what class of substances do these compounds belong? The ubiquitous presence of phenolic glycosides in plants is well known (Harborne, 1964), but these generally occur as monoglycosides (Pridham, 1965), a class that includes the glycosides of ferulic and sinapic acids. Ferulic acid has been found esterified to the pentosan moiety of a glycoprotein found in wheat (Neukom, Proviodoli, Gremli \& Hui, I967; Painter \& Neukom, 1968), but otherwise the occurrence of aromatic and heterocyclic molecules attached to polymerized carbohydrate and peptide in plants is not well known. Carbohydrates of the mol. wts found in these experiments (about 1000 to I0000 daltons, the main portion being about 2000 daltons) are known to occur in plant seeds, particularly cereals (Axelrod, 1965). Fructosans containing up to seven hexose units were extracted from wheat with hot aqueous ethanol $(800 \mathrm{ml} / \mathrm{l})$ by White \& Secor (1953). Oligopeptides of mol. wt less than 10000 have been found in ryegrass, and indeed these have been referred to as 'bound amino acids' (Carnegie, 1961, 1963; Synge, 1968). Thus the occurrence of substances of the mol. wt reported here for 
those extracted from wheat bran is well established. However, the accurrence of non-peptide, non-carbohydrate compounds, such as nicotinic acid, attached to macromolecules has not been widely studied and it may be that such compounds are not limited to the wheat seed; certainly bound nicotinic acid is known to occur in most cereals (Kodicek, i962).

We thank Mr D. R. Ashby and Mrs V. D. Wright for technical assistance in the preparation of niacytin.

\section{REFERENCES}

Axelrod, B. (1965). In Plant Biochemistry p. 245-252. [J. Bonner and J. E, Varner, editors]. London: Academic Press.

Brin, M. (1966). Meth. Enzym. 9, 500 .

Carnegie, P. R. (1961). Biochem. $\mathscr{7} .78,697$.

Carnegie, P. R. (1963). Biochem. F. 89, 459.

Chaudhuri, D. K. \& Kodicek, E. (1950). Nature, Lond. 165, 1022.

Christianson, D. D., Wall, J. S., Dimler, R. J. \& Booth, A. N. (1968). Y. Agric. Fd Chem. 16, 100.

Das, M. L. \& Guha, B. C. (1960). F. biol. Chem. 235, 2971.

Galambos, J. T. (1967). Analyt. Biochem. 19, 1 I9.

Guha, B. C. \& Das, M. L. (I957). Nature, Lond. 180 , 1285.

Hanson, L. A., Johansson, B. G. \& Rymo, L. (1966). Clinica chim. Acta I4, 39 I.

Harborne, J. B. (1964). In Biochemistry of Phenolic Compounds Ch. 4 [J. B. Harborne, editor]. London: Academic Press.

Horder, Dodds, C. \& Moran, T. (1954). In Bread p. 37. London: Constable.

Kodicek, E. (1940a). Biochem. F. 34, 7 12.

Kodicek, E. (r94ob). Biochem. F. 34, 724 .

Kodicek, E. (1962). Biblthca Nutr. Dieta 4, 109.

Kodicek, E. \& Reddi, K. K. (195I). Nature, Lond. 168, 475.

Kodicek, E. \& Wilson, P. W. (1959). Br. F. Nutr. 13, 4.18,

Kodicek, E. \& Wilson, P. W. (1960). Biochem. F. 76, 27P.

Layne, E. (1957). Meth. Enzym. 3, 450.

Lowry, O. H., Rosebrough, N. J., Farr, A. L. \& Randall, R. J. (1951). F. biol. Chem. 193, 265.

Mason, J. B. (1969). Biochemistry of niacytin. PhD Thesis, University of Cambridge.

Mason, J. B., Gibson, N. \& Kodicek, E. (197r). Biochem. F. 125, I 7 P.

Mason, J. B. \& Kodicek, E. (1970a). Biochem. F. 120, 509.

Mason, J. B. \& Kodicek, E. (1970b). Biochem. F. 120, 5 I 5.

Morris, C. J. O. R. (1964). F. Chromatog. I6, I67.

Neukom, H., Proviodoli, L., Gremli, H. \& Hui, P. (1067). Cereal Chem. 44, 238.

Painter, T. J. \& Neukom, H. (1968). Biochim. biophys. Acta 158, 363 .

Pharmacia Fine Chemicals (I966) Sephadex-Gel-filtration in Theory and Practice p. 48. Uppsala, Sweden: Beckman Hansson AB/Eklunds \& Vasatryck.

Pridham, J. B. (1965). A. Rev. Pl. Physiol. 16, I3.

Sarkar, P. K., Ghosh, H. P. \& Guha, B. C. (1962). Sci. Cult. 28, 344.

Sarkar, P. K., Ghosh, H. P. \& Guha, B. C. (1964). Int. Congr. Biochem. vi. Nezo York Abstracts vol. 5, p. 449 .

Simmonds, D. H. \& Winzor, D. J. (1961). Nature, Lond. 189, 3 o6.

Synge, R. L. M. (1968). A. Rev. Pl. Physiol. 19, 113.

Whitaker, J. R. (1963). Analyt. Chem. 35, 1950.

White, L. M. \& Secor, G. E. (1953). Archs Biophys. Biochem. 43, 60 